\title{
PENGEMBANGAN KARYAWAN DENGAN MOTIVASI SEBAGAI VARIABEL PEMODERASI TERHADAP KEPUASAN KERJA KARYAWAN BPR KEBUMEN
}

\author{
Gunarso Wiwoho \\ email: gunarsowiwoho@yahoo.co.id
}

\begin{abstract}
ABSTRAK
Kepuasan kerja karyawan merupakan salah satu elemen yang cukup penting untuk menunjang kelancaran operasional perusahaan dalam mencapai tujuannya. Sikap puas atau tidak puas karyawan dapat diukur dari sejauh mana perusahaan atau organisasi dapat memenuhi kebutuhan karyawan. Masalah yang peneliti kemukakan dalam penelitian ini adalah apakah sistem kompensasi, peluang berkarier, dan pengembangan karyawan berpengaruh terhadap kepuasan kerja dengan motivasi sebagai variabel moderat pada PT. BPR Artha Mitra Gombong.

Tujuan dari penelitian ini adalah untuk mengetahui bagaimana pengaruh sistem kompensasi, peluang berkarier, dan pengembangan karyawan dengan motivasi sebagai variabel moderat terhadap kepuasan kerja karyawan pada PT. BPR Artha Mitra Gombong, baik secara parsial maupun secara simultan.

Penelitian ini menggunakan analisis regresi berganda dan Moderated Regression Analysis ( MRA ) untuk mengetahui pengaruh sistem kompensasi (X1), peluang berkarier (X2), dan pengembangan karyawan (X3) sebagai variabel independent terhadap kepuasan kerja (Y) sebagai variabel dependent, dengan motivasi $(\mathrm{Xm})$ sebagai variabel moderat. Adapun populasi yang digunakan adalah seluruh karyawan pada PT. BPR Artha Mitra Gombong. Teknik pengumpulan data menggunakan kuesioner yang sebelumnya diuji validitas dan reliabilitasnya dengan bantuan program SPSS 12.00.

Dari hasil penelitian dan analisis data diperoleh kesimpulan bahwa secara parsial hanya variabel sistem kompensasi yang mempunyai pengaruh signifikan terhadap kepuasan kerja karyawan pada PT. BPR Artha Mitra Gombong. Sedangkan secara simultan, variabel-variabel sistem kompensasi, peluang berkarier, dan pengembangan karyawan tanpa motivasi sebagai variabel moderat mempunyai pengaruh yang signifikan terhadap kepuasan kerja karyawan pada PT. BPR Artha Mitra Gombong.

Berdasarkan kesimpulan yang telah dikemukakan, PT. BPR Artha Mitra Gombong untuk mewujudkan kepuasan kerja karyawannya disarankan untuk memperhatikan dan mengupayakan sistem kompensasi yang baik, karena variabel tersebut terbukti signifikan mempengaruhi kepuasan kerja karyawan.
\end{abstract}

Kata kunci : Sistem kompensasi, peluang berkarier, pengembangan karyawan, motivasi, dan kepuasan kerja.

\begin{abstract}
The satisfaction of employee job is one of elements that is important enough to support the fluency of company operation in achieving its goals. The satisfied or dissatisfied employees can be measured by how far the company or organization can fullfil the employee needs. The
\end{abstract}

Fokus Bisnis Vol. 9 No. 1, 2010|12 
researcher pointed out the problems of this study such as what the compensation system is, career opportunities, and employee development that affects toward job satisfaction by motivation as a moderate variable at PT BPR Kebumen.

The purpose of this study is to determine how the effect of compensation system, career opportunities, and employee development by motivation as a moderate variable toward the employee job satisfaction partially or simultaneously at PT BPR Kebumen.

This study uses multiple regression analysis and moderated regression analysis (MRA) to determine the effect of the compensation system (X1), career opportunities (X2), and employee development (X3) as the independent variable toward job satisfaction (Y) as the dependent variable, by motivation $(\mathrm{Xm})$ as a moderate variable. The researcher used all of employees who work at PT. BPR Kebumen being population. In addition data collection techniques using a questionnaire which previously tested by the validity and reliability by SPSS 12.00 .

From the results of research and data analysis can be obtained the conclusion that there is only partially variable compensation system that has a significant influence toward the employee job satisfaction at PT. BPR Kebumen. Whereas the variables of compensation system, career opportunities, and employee development without motivation as moderate variables having a significant effect simultaneously toward the employee job satisfaction at PT BPR Kebumen.

Based on the pointed out conclusion, PT. BPR Kebumen for achieving the employee job satisfaction, is suggested to notice and seek the good compensation system, because the variable is shown a significantly affect toward the employee job satisfaction.

Key words: compensation system, career opportunities, employee development, motivation and job satisfaction.

\section{PENDAHULUAN}

Sumber daya manusia atau karyawan merupakan aset yang berharga dan merupakan bagian yang terpenting bagi sebuah perusahaan. Walaupun pada saat ini banyak perusahaan yang memiliki sarana dan prasarana usaha modern untuk menunjang produktivitasnya, tetap membutuhkan sumber daya manusia untuk mengelola perusahaan dalam upaya mencapai tujuannya. Pada sebuah organisasi, anggota organisasi merupakan tonggak utama dalam menjalankan organisasi. Maju tidaknya suatu organisasi tergantung pada bagaimana anggota organisasi tersebut berusaha agar organisasi atau perusahaan tempatnya bekerja dapat mencapai tujuannya.

Setiap pemilik perusahaan dan para pemegang saham tentunya menginginkan perusahaannya dapat berjalan se-optimal mungkin dan mencapai hasil yang memuaskan. Akan tetapi terkadang mereka tidak peduli apakah selama ini semua karyawan di perusahaannya sudah puas dengan pekerjaannya.

Kepuasan kerja dirasa penting dan perlu diperhatikan oleh setiap organisasi, karena manusia merupakan faktor dan pemeran utama dalam proses kerja, terlepas dari apakah pekerjaan itu sarat teknologi atau tidak, namun pada akhirnya manusialah yang akan menjadikan pekerjaan itu efektif atau tidak ( Allen dalam As'ad, 1998 ).

Rendahnya kepuasan kerja dari karyawan dalam suatu organisasi atau perusahaan merupakan gejala dari kurang stabilnya organisasi atau perusahaan tersebut. Bentuk yang paling ekstrim dari ketidakpuasan 
tersebut adalah pemogokan kerja, mangkir, dan tingkat keluarnya karyawan dari perusahaan tinggi.

Kepuasan kerja karyawan dapat dicapai dengan memperhatikan beberapa faktor diantaranya sistem kompensasi yang memuaskan, adanya peluang untuk berkarier yang jelas, dan juga program pengembangan karyawan yang sesuai dengan kompetensi karyawan dan kebutuhan perusahaan itu sendiri.

PT. BPR Kebumen merupakan salah satu lembaga keuangan atau perbankan di Kabupaten Kebumen yang juga melakukan berbagai upaya untuk mewujudkan kepuasan kerja karyawan. Namun demikian peneliti merasakan adanya penurunan semangat dalam bekerja, kurangnya motivasi, serta keinginan untuk keluar dari perusahaan yang cukup tinggi dari beberapa karyawan PT. BPR Kebumen.

Dari data yang ada sejak tahun 2005 sampai dengan tahun 2009 tercatat sebanyak empat orang karyawan telah mengundurkan diri dari PT. BPR Kebumen. Ini berarti hampir setiap tahun ada seorang karyawan yang keluar dari perusahaan dengan kehendaknya sendiri. Tentunya ada sesuatu hal yang melatar belakangi keputusan mereka untuk keluar.

Selain itu peneliti juga ingin mengetahui bagaimana motivasi karyawan PT. BPR Kebumen dalam bekerja dapat memberi pengaruh yang lebih, baik positif ataupun negatif terhadap kepuasan kerja di samping pengaruh yang ditimbulkan dari sistem kompensasi, peluang berkarier, dan pengembangan karyawan yang diterapkan di PT. BPR Kebumen.

\section{KAJIAN PUSTAKA}

\section{Kompensasi}

Gary Dessler ( dalam Panudju, 2003 ) mendefinisikan kompensasi sebagai berikut : employee compensastion is all forms of pay rewards going to employee and arising from their employment. Maksudnya kompensasi adalah segala bentuk pembayaran atau imbalan yang diberikan kepada karyawan oleh perusahaan sebagai balas jasa atas kontribusi mereka kepada perusahaan.

Menurut Werther dan Davis ( dalam Hasibuan, 2003 ) mendefinisikan kompensasi adalah apa yang seorang pekerja terima sebagai balasan dari pekerjaan yang diberikan kepadanya.

Berdasarkan uraian di atas sistem kompensasi merupakan program yang dijalankan oleh suatu perusahaan dalam memberikan pembayaran atau imbalan kepada karyawannya sebagai balas jasa atas kontribusi mereka kepada perusahaan.

\section{Jenis Kompensasi}

Jenis-jenis kompensasi menurut beberapa pendapat diantaranya adalah sebagai berikut : a. Menurut Mondy dan Neo ( 1993 ) jenis kompensasi yang diberikan kepada karyawan dapat berbentuk :

1. Kompensasi Finansial

Kompensasi yang diterima karyawan dalam bentuk finansial, seperti gaji, upah, bonus, dan tunjangan-tunjangan.

2. Kompensasi Non-finansial

Kompensasi yang diterima karyawan dalam bentuk non-finansial, seperti promosi jabatan dan penghargaan.

b. Kompensasi menurut Mathis dan Jackson ( 2006 ) dibedakan menjadi dua jenis, yaitu :

1. Kompensasi Langsung Meliputi gaji pokok, upah, dan penghasilan tidak tetap seperti bonus, insentif, atau opsi saham.

2. Kompensasi Tidak Langsung Meliputi tunjangan-tunjangan seperti asuransi kesehatan/jiwa, cuti berbayar, dana pensiun, dan kompensasi pekerja. 
c. Jenis kompensasi yang didapat oleh karyawan ada 2 (dua) macam (Nurachmad, 2009) :

\section{Profit / Keuntungan}

Kompensasi berupa materi yang dibayarkan secara langsung, seperti gaji, upah, bonus, dan insentif.

\section{Benefit / Kesejahteraan}

Kompensasi atau kemanfaatan berupa non-materi untuk memenuhi kebutuhan dan/atau keperluan yang bersifat jasmaniah dan rohaniah, baik di dalam maupun di luar hubungan kerja, yang secara langsung atau tidak langsung dapat mempertinggi produktivitas kerja dalam lingkungan kerja yang aman dan sehat. Diantaranya adalah jaminan kesehatan, jaminan hari tua, jaminan kecelakaan kerja, jaminan kematian, kredit perumahan, koperasi karyawan, dan sebagainya.

\section{Komponen Sistem Kompensasi Total}

Menurut Schuler dan Jackson ( 1999 ) sistem kompensasi total terdiri atas komponen-komponen sebagai berikut :

\section{Kompensasi Moneter}

1. Kompensasi langsung, meliputi gaji pokok, bonus, insentif, dan pembagian saham.

2. Kompensasi tidak langsung ( tunjangan ), meliputi :

a. Perlindungan umum : jaminan sosial, pengangguran, cacat.

b. Perlindungan pribadi : pensiun, tabungan, asuransi, pesangon.

c. Bayaran tidak masuk kantor : pelatihan, cuti kerja, sakit, liburan.

d. Tunjangan siklus hidup : bantuan hukum, perawatan orang tua, perawatan anak, program kesehatan.

Tujuan dan pentingnya perusahaan memberikan kompensasi moneter :

1. Menarik pelamar kerja yang potensial.
2. Mempertahankan karyawan yang baik.

3. Meraih keunggulan kompetitif.

4. Meningkatkan produktivitas.

5. Melakukan pembayaran sesuai aturan hukum.

6. Memudahkan sasaran strategis.

7. Mengokohkan dan menentukan struktur.

\section{Kompensasi Nonmoneter}

1. Imbalan karier, meliputi rasa aman, pengembangan diri, fleksibilitas karier, peluang kenaikan penghasilan.

2. Imbalan sosial, meliputi simbol status, pujian dan pengakuan, kenyamanan tugas, persahabatan.

\section{Azas-Azas Kompensasi}

Agar dalam pelaksanaannya program kompensasi dapat berjalan secara efektif, maka program kompensasi tersebut harus menerapkan azas-azas kompensasi Hasibuan, 2001 ), yaitu :

1. Azas adil; artinya besarnya kompensasi yang diberikan kepada karyawan harus disesuaikan dengan prestasi kerja, jenis pekerjaan, resiko pekerjaan, tanggung jawab, jabatan pekerjaan, dan memenuhi persyaratan internal konsisten.

2. Azas layak dan wajar; artinya kompensasi yang diberikan kepada karyawan harus dapat memenuhi kebutuhannya pada tingkat normatif yang ideal.

Selain itu beberapa hal yang perlu dilakukan dalam usaha pengembangan suatu sistem kompensasi, antara lain :

1. Melakukan analisis pekerjaan.

2. Melakukan penilaian terhadap pekerjaan dikaitkan dengan keadilan internal.

3. Melakukan survei terhadap berbagai sistem imbalan yang berlaku di organisasi 
lain, guna memperoleh bahan yang berkaitan dengan keadilan eksternal.

4. Menentukan harga setiap pekerjaan dihubungkan dengan harga pekerjaan yang sejenis di tempat lain.

\section{Peluang Berkarier}

Pada dasarnya setiap manusia ingin selalu berkembang atau maju dalam segala hal. Demikian pula dengan karyawan yang bekerja di perusahaan, mereka ingin lebih maju dan berkembang. Perwujudan kemajuan ini tampak dalam perkembangan karier karyawan. Seseorang yang berkarier dari bawah tentu mengharapkan suatu saat nanti dapat mencapai karier setinggi mungkin. Dengan demikian karyawan akan merasa puas karena ada hasil dan penghargaan dari jerih payahnya selama ini di samping penghasilan dan gaji tentunya.

\section{Konsep Dasar Perencanaan Karier}

\section{Pengertian Karier}

Karier adalah seluruh posisi kerja yang dijabat selama siklus kehidupan pekerjaan seseorang ( Bacal, 2002 ).

Karier menurut Mathis dan Jackson ( 2006: 342 ) adalah rangkaian posisi yang berkaitan dengan kerja yang ditempati seseorang sepanjang hidupnya.

2. Jenjang Karier

Model posisi pekerjaan berurutan yang membentuk karier seseorang.

3. Tujuan Karier

Merupakan posisi mendatang yang diupayakan pencapaiannya oleh seseorang sebagai bagian kariernya.

4. Perencanaan Karier

Proses dimana seseorang menyeleksi tujuan karier dan jenjang karier menuju tujuan-tujuan tersebut.

5. Pengembangan Karier

Terdiri dari peningkatan pribadi yang dilakukan oleh seseorang dalam mencapai rencana karier pribadinya.

\section{Keinginan Karyawan}

Peluang berkarier merupakan keinginan sebagian besar karyawan dalam bekerja yang mengharapkan akan adanya hal-hal sebagai berikut :

1. Persamaan Karier ( career equity)

Adanya persamaan di dalam sistem promosi dalam rangka mendapatkan kesempatan karier yang lebih tinggi.

2. Masalah Pengawasan ( supervisory concern )

Karyawan menginginkan di dalam pengembangan kariernya ada peran aktif para pengawas serta dapat memberikan umpan balik bagi prestasi kerjanya.

3. Kesadaran Akan Adanya Kesempatan ( awareness of opportunity )

Adanya pengetahuan yang memadai mengenai kesempatan untuk karier yang lebih tinggi di masa mendatang.

4. Minat Karyawan (employment interest) Karyawan membutuhkan informasi dalam jumlah yang berbeda dan memiliki tingkat minat yang berbeda terhadap karier yang akan datang.

5. Kepuasan Karier ( career satisfaction ) Tingkat kepuasan karier karyawan berbeda-beda tergantung pada usia dan pendidikan karyawan tersebut.

\section{Strategi Meningkatkan Karier}

Ada beberapa cara yang bisa ditempuh karyawan untuk mengejar karier. Lima macam strategi untuk meningkatkan karier ( Guthrie, Coate,

dan Schwoerer, 1998 ), yaitu :

1. Memperoleh bimbingan dari atasan atau karyawan senior

2. Meniti karier secara fleksibel

3. Membangun jaringan kerja

4. Bekerja dengan melibatkan diri lebih dalam 
5. Menampilkan diri secara intensif

Faktor-Faktor yang Mempengaruhi Pemilihan Karier

1. Minat, orang cenderung mengejar karier yang mereka percaya sesuai dengan minatnya.

2. Citra diri, karier dianggap sebagai perluasan dari citra diri seseorang.

3. Kepribadian, individu yang memiliki kepribadian tertentu mempunyai orientasi pribadi dan kebutuhan pribadi yang berbeda dalam bekerja.

4. Latar belakang sosial, status sosialekonomi, tingkat pendidikan, dan pekerjaan orang tua seseorang juga merupakan faktor yang mempengaruhi dalam pemilihan karier.

\section{Pengembangan Karyawan}

Pengembangan adalah proses pendidikan jangka panjang yang mempergunakan prosedur sistematis dan terorganisir sehingga tenaga kerja manajerial mempelajari pengetahuan konseptual dan teoritis untuk tujuan umum ( Sikula, 1976 ).

Menurut Heidjraman Ranupandojo (1999:77) pengembangan karyawan adalah usaha untuk meningkatkan ketrampilan maupun pengetahuan umum bagi karyawan agar pelaksanaan untuk mencapai tujuan lebih efisien.

Pengembangan adalah suatu usaha untuk meningkatkan kemampuan teknis, teoritis, dan moral karyawan sesuai dengan kebutuhan pekerjaan/ jabatan melalui pendidikan dan latihan (Budiarsa Dharmatanna, 2008 ).

Jadi pengembangan karyawan merupakan usaha untuk lebih menguasai ketrampilan dan teknik dalam pelaksanaan pekerjaan tertentu serta sebagai upaya untuk menyesuaikan diri dengan kemajuan teknologi.

\section{Motivasi}

Setiap orang/karyawan memiliki motivasi dalam bekerja. Motivasi merupakan sesuatu yang mendorong atau menggerakkan seseorang untuk bertindak dengan cara tertentu. Motivasi seseorang timbul dari keinginan untuk berinteraksi, ingin mencapai tujuan yang telah ditetapkan, kreatif, dan dapat mengarahkan diri sendiri.

Motivasi berasal dari kata Latin movere, yang berarti menggerakkan ( to move ). Motivation is an internal process through which needs and desires are satisfied (Catt \& Miller,1991 ), yang maksudnya adalah proses dalam diri manusia yang mendorong manusia untuk melakukan aktivitas dan perilaku tertentu untuk memenuhi tujuannya.

Motivasi juga didefinisikan sebagai kesediaan untuk mengeluarkan tingkat upaya yang tinggi untuk tujuan organisasi, yang dikondisikan oleh kemampuan upaya itu dalam memenuhi beberapa kebutuhan individual (Robbins, 2001).

Menurut Mathis dan Jackson ( 2006: 114 ) motivasi adalah keinginan dalam diri seseorang yang menyebabkan orang tersebut bertindak. Jadi motivasi merupakan dorongan yang diatur oleh tujuan dan jarang muncul dalam kekosongan.

Motivasi dapat dibedakan menjadi 2 jenis yaitu intrinsik dan ekstrinsik yang maksudnya adalah :

1. Motivasi Intrinsik

Tanggung jawab, kebebasan untuk bertindak, lingkup untuk menggunakan serta mengembangkan keterampilan dan kemampuan, pekerjaan dan peluang yang menarik dan menantang untuk pencapaian tindakan.

2. Motivasi Ekstrinsik

Berhubungan dengan lingkungan di sekitar pekerjaan, misal kenaikan imbalan, pujian dari atasan, status, kondisi kerja, promosi, keamanan dan 
keselamatan kerja, dan sebagainya.

\section{Kepuasan Kerja}

Kepuasan kerja karyawan merupakan salah satu elemen yang cukup penting untuk menunjang kelancaran operasional perusahaan dalam mencapai tujuannya. Hal ini disebabkan kepuasan kerja dapat mempengaruhi perilaku kerja seseorang seperti malas, rajin, produktif, apatis, dan lain-lain. Sikap puas atau tidak puas karyawan dapat diukur dari sejauh mana perusahaan atau organisasi dapat memenuhi kebutuhan karyawan.

Bila terjadi keserasian antara kebutuhan karyawan dengan apa yang diberikan perusahaan, maka tingkat kepuasan yang dirasakan karyawan akan tinggi, dan sebaliknya. Ketidakpuasan kerja sering tercermin dari prestasi yang rendah, tingkat kemangkiran yang tinggi, seringnya terjadi kecelakaan kerja, dan bahkan pemogokan kerja yang pada akhirnya akan sangat merugikan perusahaan.

Kepuasan kerja diartikan sebagai "the way an employee feels about his or her job")( Wexley dan Yuki dalam As'ad, 1987 ). Artinya bahwa kepuasan kerja adalah cara pegawai merasakan dirinya atau pekerjaannya. Dapat disimpulkan bahwa kepuasan kerja adalah perasaan yang menyokong atau tidak menyokong dalam diri pegawai yang berhubungan dengan pekerjaan maupun kondisi dirinya. Perasaan yang berhubungan dengan pekerjaan melibatkan aspek-aspek seperti upaya, kesempatan pengembangan karier, hubungan dengan pegawai lain, penempatan kerja, dan struktur organisasi. Sementara itu, perasaan yang berhubungan dengan dirinya antara lain berupa umur, kondisi kesehatan, kemampuan dan pendidikan.

Siagian menuliskan bahwa "kepuasan kerja merupakan suatu cara pandang seseorang, baik yang bersifat positif maupun bersifat negatif tentang pekerjaannya"( Siagian, 2000 ). Dapat diartikan bahwa kepuasan kerja merupakan perasaan positif seseorang terhadap pekerjaannya.

Menurut Werther dan Davis ( dalam Iriyanto, 2005 ) kepuasan kerja adalah perasaan menyenangkan dan tidak menyenangkan, menurut pandangan para pekerja terhadap pekerjaannya. Kepuasan kerja diperoleh bila ada kesesuaian antara ciri-ciri pekerjaan ( job characteristics ) dengan keinginan para pekerja.

Kepuasan kerja ( job satisfaction ) adalah keadaan emosional yang positif yang merupakan hasil dari evaluasi pengalaman kerja seseorang (Mathis dan Jackson, 2006). Ketidakpuasan kerja muncul ketika harapan seseorang tidak terpenuhi.

Jadi dapat dikatakan kepuasan kerja adalah keadaan emosional yang menyenangkan dengan mana para karyawan memandang pekerjaan mereka. Ini dampak dari sikap positif karyawan terhadap pekerjaan dan segala sesuatu yang dihadapi di lingkungan kerjanya.

\section{Dampak Sistem Kompensasi, Peluang} Berkarier, Pengembangan Karyawan, dan Motivasi terhadap Kepuasan Kerja

Kepuasan kerja berkaitan erat dengan kualitas kehidupan kerja atau quality work of life. Kualitas kehidupan kerja merupakan suatu upaya untuk memenuhi kebutuhan tingkat tinggi karyawan dan kebutuhan yang lebih pokok ( Davis dan Newstrom, 1985 ). Gagasannya adalah bahwa karyawan merupakan sumber daya manusia yang perlu dikembangkan, bukan sekedar digunakan.

Kehidupan kerja berkualitas menurut Schuler dan Jackson ( 1999 ) terwujud jika kondisi tempat kerja dapat memenuhi preferensi-preferensi dan minat-minat tertentu seperti rasa tanggung jawab, 
keinginan akan pemberdayaan dan Newstrom ( 1985 ) adalah telaah dan keterlibatan dalam pekerjaan, tantangan, harga diri, pengendalian diri, penghargaan, prestasi, keadilan, keamanan, dan kepastian. Termasuk di dalamnya keberadaan sistem kompensasi yang obyektif, jenjang karier yang jelas, program pengembangan karyawan, dan adanya motivasi dari karyawan yang dapat memperkuat pengaruh ketiga hal tersebut dalam mewujudkan kehidupan kerja berkualitas yang pada akhirnya akan tercipta kepuasan kerja dari setiap karyawan.

\section{Kerangka Teoritis}

Kerangka teoritis ini untuk memperjelas inti bahasan dari penelitian yang peneliti susun. Yaitu untuk membahas variabel sistem kompensasi, peluang berkarier, dan pengembangan karyawan yang berpengaruh dan menunjukkan hubungan dengan variabel kepuasan kerja.

Kemudian bagaimana ketiga variabel bebas tersebut diinteraksikan dengan motivasi, apakah akan memperkuat pengaruh atau melemahkan pengaruh ketiga variable bebas tersebut terhadap variabel kepuasan kerja.

Penempatan motivasi sebagai variabel moderat didasarkan pada peranan perilaku organisasi dalam mencapai kepuasan kerja. Perilaku organisasi menurut Davis dan

penerapan pengetahuan tentang bagaimana orang-orang bertindak di dalam organisasi. Tujuannya membantu menyatukan orangorang, struktur, teknologi, dan lingkungan eksternal menjadi sistem pengoperasian yang efektif untuk mencapai pemenuhan kebutuhan manusia, tujuan organisasi, dan sosial.

Dalam perilaku organisasi disebutkan bahwa pikiran manusia didorong untuk lebih kreatif dengan motivasi yang positif. Ini merupakan kekuatan menggerakkan yang unik yang secara keseluruhan tidak serupa dengan penerapan energi fisik dalam mesin. Jadi seseorang dapat menghasilkan jumlah yang tidak terbatas melalui gagasan yang lebih baik. Dengan adanya perilaku organisasi yang lebih baik akan memotivasi orang untuk menghasilkan gagasan yang lebih baik. Gagasan yang baik tersebut akan menghasilkan prestasi kerja yang dapat memberikan kepuasan bagi karyawan yang bersangkutan. Persamaannya adalah sebagai berikut ( Davis dan Newstrom, 1985 ): kemampuan $X$ motivasi $=$ prestasi manusia.

Jadi motivasi dan kemampuan secara bersama menentukan potensi prestasi seseorang dalam suatu aktivitas 


\section{Kerangka Teoritis}

\section{Gambar 1 Kerangka Teoritis}

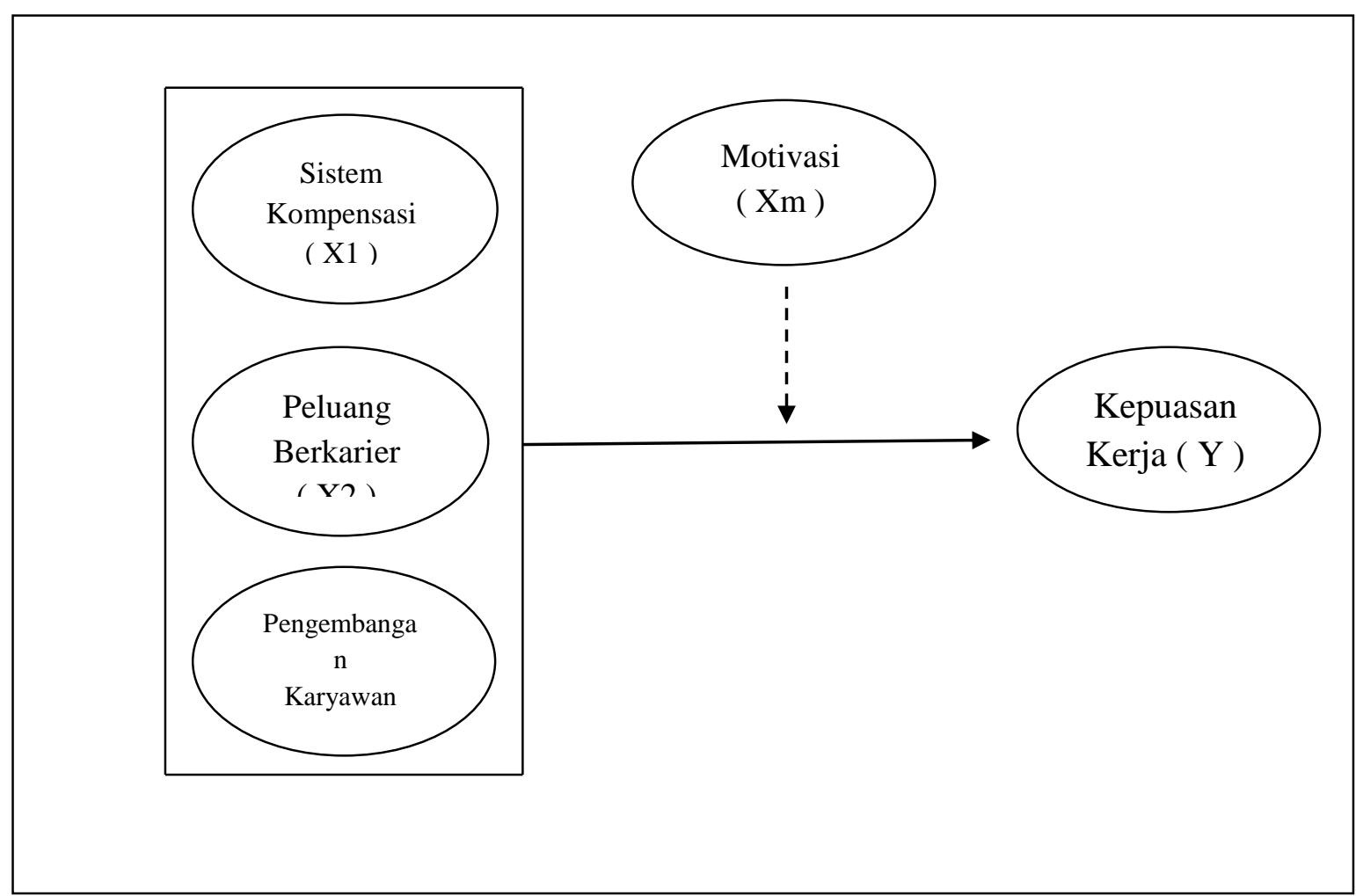

\section{Hipotesis}

Hipotesis merupakan jawaban sementara dari sebuah permasalahan yang harus dibuktikan kebenarannya. Hipotesis dari penelitian ini adalah sebagai berikut :

H1 : Terdapat pengaruh sistem kompensasi terhadap kepuasan kerja karyawan di PT BPR Kebumen.

H2 : Terdapat pengaruh peluang berkarir terhadap kepuasan kerja

karyawan di PT. BPR Kebumen.

H3 :Terdapat pengaruh pengembangan karyawan terhadap kepuasan kerja karyawan di PT. BPR Kebumen.

H4 : Terdapat pengaruh motivasi terhadap kepuasan kerja karyawan di PT. BPR Kebumen.

H5 : Terdapat pengaruh sistem kompensasi terhadap kepuasan kerja dengan motivasi sebagai variabel moderat pada PT. BPR Kebumen.

H6 : Terdapat pengaruh peluang berkarier terhadap kepuasan kerja dengan motivasi sebagai variabel moderat pada PT. BPR Kebumen.

H7 :Terdapat pengaruh pengembangan karyawan terhadap kepuasan kerja dengan motivasi sebagai variabel moderat pada PT. BPR Kebumen.

H8 : Secara simultan variabel sistem kompensasi, peluang berkarier,

dan pengembangan karyawan berpengaruh terhadap kepuasan kerja karyawan pada PT. BPR Kebumen.

H9 : Secara simultan variabel sistem kompensasi, peluang berkarier, dan pengembangan karyawan berpengaruh terhadap kepuasan kerja dengan motivasi sebagai variabel moderat pada PT. Kebumen. 


\section{METODOLOGI PENELITIAN}

\section{Populasi Penelitian}

Populasi, yaitu wilayah generalisasi yang terdiri atas obyek atau subyek yang mempunyai kuantitas dan karakteristik tertentu yang ditetapkan oleh peneliti untuk dipelajari dan kemudian ditarik kesimpulannya (Sugiyono, 2005). Populasi dalam penelitian ini adalah seluruh karyawan di PT. BPR Kebumen sebanyak 30 orang.

\section{Variabel Penelitian}

1. Variabel Bebas: variabel ini sering disebut sebagai variabel independent, stimulus, predictor, antecedent. Variabel bebas adalah merupakan variabel yang mempengaruhi atau yang menjadi sebab perubahannya atau timbulnya variabel terikat ( dependen ). Variabel bebas dalam penelitian ini adalah :
a. Sistem kompensasi sebagai X1
b. Peluang berkarier sebagai X2
c. Pengembangan karyawan sebagai $\mathrm{X} 3$

2. Variabel Moderat: adalah variabel yang mempengaruhi (memperkuat dan memperlemah) hubungan antara variabel independen dengan dependen. Variabel moderat dalam penelitian ini adalah motivasi $(\mathrm{Xm})$.

3. Variabel Terikat: sering disebut sebagai variabel dependen, output, kriteria, konsekuen. Variabel terikat merupakan variabel yang dipengaruhi atau yang menjadi akibat, karena adanya variabel bebas. Variabel terikat dalam penelitian ini adalah kepuasan kerja ( Y ).

\section{Model Penelitian}

Untuk mengetahui pengaruh dari ketiga variabel bebas ( sistem kompensasi, peluang berkarier, dan pengembangan karyawan ) terhadap variabel terikat ( kepuasan kerja ) dengan bantuan program SPSS for Windows seri 12. Rumus yang digunakan :

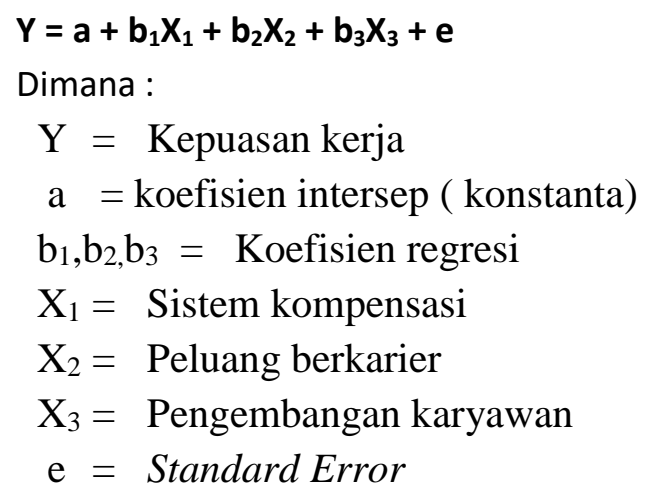

\section{Moderated Regression Analysis ( MRA )}

Menurut Imam Ghozali ( 2005 ), Moderated Regression Analysis (MRA) adalah spesifikasi regresi linear yang memasukkan variabel ketiga berupa perkalian antara dua variabel independen sebagai variabel moderating. MRA ini digunakan untuk menganalisis pengaruh interaksi dari ketiga variabel bebas ( sistem kompensasi, peluang berkarier, dan pengembangan karyawan ) terhadap variabel terikat (kepuasan kerja) dengan motivasi sebagai variabel moderat menggunakan bantuan program SPSS for Windows seri 12. Rumus yang digunakan :

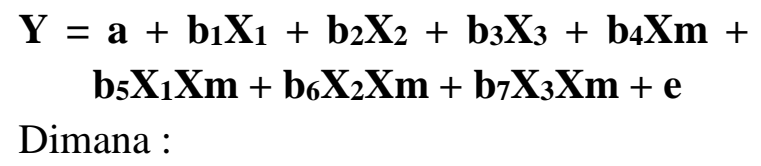

$\mathrm{Y}=$ Kepuasan kerja

$\mathrm{a}=$ Koefisien intersep( konstanta)

$\mathrm{b}_{1}, \mathrm{~b}_{2}, \mathrm{~b}_{3}, \mathrm{~b}_{4}, \mathrm{~b}_{5}, \mathrm{~b}_{6}, \mathrm{~b}_{7}=$ Koefisien regresi

$\mathrm{X}_{1}=$ Sistem kompensasi

$\mathrm{X}_{2}=$ Peluang berkarier

$\mathrm{X}_{3}=$ Pengembangan karyawan

$\mathrm{Xm}=$ Motivasi

$\mathrm{X}_{1} \mathrm{Xm}=$ Interaksi sistem kompensasi dengan motivasi

$\mathrm{X}_{2} \mathrm{Xm}=$ Interaksi peluang berkarier dengan motivasi

$\mathrm{X}_{3} \mathrm{Xm}=$ Interaksi pengembangan karyawan dan motivasi 
$\mathrm{e}=$ Standard Error

\section{Uji Validitas}

Suatu instrumen dikatakan valid apabila mampu mengukur apa yang diinginkan dan mengungkap data dari variabel yang diteliti secara tepat. Untuk mengetahui valid tidaknya kuesioner dalam penelitian ini dilakukan dengan mengkorelasikan variabel dengan total itemitemnya dengan menggunakan korelasi product moment, responden untuk uji ini berjumlah 30 orang. Dengan derajat kebebasan (n-2) atau (30-2) $=28$ dan $\alpha=0,05$ diperoleh angka $r$ tabel sebesar 0,374. Adapun hasil uji validitas variabel dalam penelitian ini adalah sebagai berikut :

\section{Variabel Sistem Kompensasi ( X1 )}

Tabel 1 Hasil Uji Validitas Sistem Kompensasi

\begin{tabular}{||c|c|c|c||}
\hline BUTIR & r hasil & $\mathbf{r}$ tabel & KETERANGAN \\
\hline 1 & 0,635 & 0,374 & Valid \\
\hline 2 & 0,910 & 0,374 & Valid \\
\hline 3 & 0,823 & 0,374 & Valid \\
\hline 4 & 0,619 & 0,374 & Valid \\
\hline 5 & 0,910 & 0,374 & Valid \\
\hline
\end{tabular}

Dari tabel tersebut dapat dijelaskan bahwa $\mathrm{r}$ hasil $>\mathrm{r}$ tabel, hal ini berarti seluruh pertanyaan yang digunakan dalam variabel sistem kompensasi dinyatakan valid.

\section{Variabel Peluang Berkarier ( X2 )}

Tabel 2. Hasil Uji Validitas Peluang Berkarier

\begin{tabular}{||c|c|c|c||}
\hline BUTIR & r hasil & r tabel & KETERANGAN \\
\hline 1 & 0,859 & 0,374 & Valid \\
\hline 2 & 0,780 & 0,374 & Valid \\
\hline 3 & 0,810 & 0,374 & Valid \\
\hline
\end{tabular}

Dari tabel di atas dapat dijelaskan bahwa $\mathrm{r}$ hasil $>\mathrm{r}$ tabel, hal ini berarti seluruh pertanyaan yang digunakan dalam variabel peluang berkarier dinyatakan valid.

\section{Variabel Pengembangan Karyawan ( X3 )}

Tabel 3 Hasil Uji Validitas Pengembangan Karyawan

\begin{tabular}{|c|c|c|c||}
\hline BUTIR & r hasil & r tabel & KETERANGAN \\
\hline 1 & 0,789 & 0,374 & Valid \\
\hline 2 & 0,705 & 0,374 & Valid \\
\hline 3 & 0,707 & 0,374 & Valid \\
\hline 4 & 0,566 & 0,374 & Valid \\
\hline
\end{tabular}

Dari tabel di atas dapat dijelaskan bahwa $\mathrm{r}$ hasil $>\mathrm{r}$ tabel, hal ini berarti seluruh pertanyaan yang digunakan dalam variabel pengembangan karyawan dinyatakan valid.

\section{Variabel Motivasi ( $\mathrm{Xm}$ )}

Tabel 4 Hasil Uji Validitas Motivasi

\begin{tabular}{||c|c|c|c||}
\hline BUTIR & r hasil & r tabel & KETERANGAN \\
\hline 1 & 0,817 & 0,374 & Valid \\
\hline 2 & 0,699 & 0,374 & Valid \\
\hline 3 & 0,665 & 0,374 & Valid \\
\hline 4 & 0,901 & 0,374 & Valid \\
\hline
\end{tabular}

Fokus Bisnis Vol. 9 No. 1, $2010 \mid 22$ 


\begin{tabular}{|l|l|l|l||}
\hline \hline 5 & 0,454 & 0,374 & Valid \\
\hline
\end{tabular}

Dari tabel di atas dapat dijelaskan bahwa $r$ hasil $>r$ tabel, hal ini berarti seluruh pertanyaan yang digunakan dalam variabel motivasi dinyatakan valid.

\section{Variabel Kepuasan Kerja ( Y )}

Tabel 5. Hasil Uji Validitas Kepuasan Kerja

\begin{tabular}{||c|c|c|c||}
\hline \hline BUTIR & r hasil & r tabel & KETERANGAN \\
\hline 1 & 0,814 & 0,374 & Valid \\
\hline 2 & 0,670 & 0,374 & Valid \\
\hline 3 & 0,649 & 0,374 & Valid \\
\hline 4 & 0,621 & 0,374 & Valid \\
\hline 5 & 0,804 & 0,374 & Valid \\
\hline
\end{tabular}

Dari tabel di atas dapat dijelaskan bahwa $r$ hasil $>r$ tabel, hal ini berarti seluruh pertanyaan yang digunakan dalam variabel kepuasan kerja dinyatakan valid.

\section{Uji Reliabilitas}

Uji reliabilitas digunakan untuk menunjukkan sejauh mana suatu hasil pengukuran relatif konsisten apabila pengukuran diulangi dua kali atau lebih. Untuk mengukur apakah suatu instrumen reliabel atau tidak dapat dilihat pada tabel Reliability Statistic, jika Cronbach's Alpha variable > 0,60 maka dapat dikatakan variabel tersebut reliabel (Ghozali, 2005:42).

Tabel 6 Hasil Uji Reliabilitas

\begin{tabular}{||l|c|c|c||}
\hline VARIABEL & $\begin{array}{c}\text { Cronbach's } \\
\text { Alpha }\end{array}$ & $\begin{array}{c}\text { Nilai } \\
\text { Kritis }\end{array}$ & KET \\
\hline $\begin{array}{l}\text { Sistem } \\
\text { Kompensasi }\end{array}$ & 0,842 & 0,60 & Reliabel \\
\hline $\begin{array}{l}\text { Peluang } \\
\text { Berkarier }\end{array}$ & 0,744 & 0,60 & Reliabel \\
\hline $\begin{array}{l}\text { Pengembangan } \\
\text { Karyawan }\end{array}$ & 0,607 & 0,60 & Reliabel \\
\hline Motivasi & 0,736 & 0,60 & Reliabel \\
\hline Kepuasan kerja & 0,754 & 0,60 & Reliabel \\
\hline
\end{tabular}

Berdasarkan tabel di atas hasil analisis dapat dijelaskan bahwa seluruh variabel dalam penelitian ini dinyatakan reliabel karena Cronbach's Alpha seluruh variabel > 0,60 .

\section{Analisis Regresi Berganda}

Analisis ini digunakan untuk mengetahui pengaruh dari variabel-variabel sistem kompensasi, peluang berkarier, dan pengembangan karyawan terhadap kepuasan kerja karyawan pada PT. BPR Kebumen.
Rumus yang digunakan adalah :

$$
\mathbf{Y}=\mathbf{a}+\mathbf{b}_{1} \mathbf{X}_{1}+\mathbf{b}_{2} \mathbf{X}_{2}+\mathbf{b}_{3} \mathbf{X}_{3}+\mathbf{e}
$$

Adapun hasil analisisnya adalah sebagai berikut :

\section{Tabel 7. Koefisien Regresi}

\begin{tabular}{|c|c|}
\hline Notasi & Koefisien \\
\hline $\mathrm{a}$ & 0,959 \\
$\mathrm{~b}_{1}$ & 0,484 \\
$\mathrm{~b}_{2}$ & 0,065 \\
$\mathrm{~b}_{3}$ & 0,265 \\
\hline
\end{tabular}

Sumber : Hasil Olah Data 
Berdasarkan tabel di atas maka dapat dibuat persamaan regresinya sebagai berikut : $Y=0,959+0,484 X_{1}+0,065 X_{2}+0,265 X_{3}$ $+\mathbf{e}$

Kemudian nilai-nilai tersebut di atas dapat dijelaskan satu persatu sebagai berikut

1. Konstanta ( a $)=0,959$

Menunjukkan nilai konstanta atau nilai tetap yang tidak terpengaruh oleh sistem kompensasi, peluang berkarier, dan pengembangan karyawan. Artinya apabila perusahaan tidak memberikan sistem kompensasi, peluang berkarier, dan pengembangan karyawan maka kepuasan kerja karyawan sebesar 0,959.

2. Variabel Independen

a. $b_{1}=0,484$, Koefisien regresi untuk $X_{1}$ sebesar 0,484 artinya setiap penambahan 1 satuan pada variabel sistem kompensasi maka akan meningkatkan kepuasan kerja karyawan sebesar 0,484. $\mathrm{b}_{2}=0,065$, Koefisien regresi untuk $\mathrm{X}_{2}$ sebesar 0,065 artinya setiap penambahan 1 satuan pada variabel peluang berkarier maka akan meningkatkan kepuasan kerja karyawan sebesar 0,065.

$b_{3}=0,265$, Koefisien regresi untuk $X_{3}$ sebesar 0,265 artinya setiap penambahan 1 satuan pada variabel pengembangan karyawan maka akan meningkatkan kepuasan kerja karyawan sebesar 0,265.

\section{Uji Parsial ( Uji t )}

Pengujian ini digunakan untuk mengetahui apakah variabel bebas secara sendiri-sendiri mempunyai pengaruh yang signifikan terhadap variabel terikat ( $\mathrm{Y}$ ). Untuk mengetahui hasil analisis uji t dapat dilihat pada tabel berikut :

Tabel 8. Tingkat Signifikan Koefisien Regresi

\section{Coefficients(a)}

\begin{tabular}{|l|c|c|c|c|c|c|}
\hline \multicolumn{2}{|c|}{} & \multicolumn{2}{|c|}{$\begin{array}{l}\text { Unstandardized } \\
\text { Coefficients }\end{array}$} & $\begin{array}{c}\text { Standardized } \\
\text { Coefficients }\end{array}$ & $\mathrm{t}$ & Sig. \\
\cline { 3 - 7 } \multicolumn{2}{|l}{ Model } & $\mathrm{B}$ & $\begin{array}{c}\text { Std. } \\
\text { Error }\end{array}$ & Beta & & \\
\hline 1 & (Const & .959 & .852 & & 1.126 & .270 \\
& ant) & & & & & \\
& X1 & .484 & .170 & .485 & 2.847 & .009 \\
& X2 & .065 & .140 & .080 & .467 & .644 \\
& X3 & .265 & .209 & .215 & 1.271 & .215 \\
\hline
\end{tabular}

a Dependent Variable: Y

Sumber : Hasil Olah Data

Fokus Bisnis Vol. 9 No. 1, 2010 | 24 
Pengambilan keputusan :

1. Jika tingkat signifikan variabel bebas < 0,05 maka variabel tersebut mempunyai pengaruh signifikan terhadap Y.

2. Jika tingkat signifikan variabel bebas > 0,05 maka variabel tersebut tidak mempunyai pengaruh signifikan terhadap Y.

Dengan demikian tabel di atas menunjukkan bahwa :

1. Variabel sistem kompensasi mempunyai pengaruh yang signifikan terhadap kepuasan kerja karyawan. Ini ditunjukkan dengan tingkat signifikan $0,009<0,05$.

2. Variabel peluang berkarier tidak mempunyai pengaruh yang signifikan terhadap kepuasan kerja karyawan. Ini ditunjukkan dengan tingkat signifikan $0,644>0,05$.

3. Variabel pengembangan karyawan tidak mempunyai pengaruh yang signifikan terhadap kepuasan kerja karyawan. Ini ditunjukkan dengan tingkat signifikan $0,215>0,05$.

\section{Uji Simultan (UjiF)}

Tabel 9 Hasil Uji F

$\operatorname{ANOVA}(b)$

\begin{tabular}{|c|c|c|c|c|c|c|}
\hline \multicolumn{2}{|c|}{ Model } & $\begin{array}{l}\text { Sum of } \\
\text { Squares }\end{array}$ & df & Mean Square & $\mathrm{F}$ & Sig. \\
\hline \multirow[t]{3}{*}{1} & $\begin{array}{l}\text { Regressio } \\
n\end{array}$ & 1.427 & 3 & .476 & 3.113 & $.043(a)$ \\
\hline & Residual & 3.972 & 26 & .153 & & \\
\hline & Total & 5.399 & 29 & & & \\
\hline
\end{tabular}

a Predictors: (Constant), X3, X1, X2

b Dependent Variable: Y

Sumber : Hasil Olah Data

Pengujian ini dilakukan untuk mengetahui pengaruh secara bersama-sama ( simultan ) antara variabel-variabel bebas terhadap variabel kepuasan kerja ( Y ). Dari hasil pengolahan data seperti terlihat dalam tabel di atas diperoleh tingkat signifikan 0,043 < 0,05 yang artinya variabel sistem

\section{Koefisien Determinasi ( $\mathbf{R}^{2}$ )}

kompensasi, variabel peluang berkarier, dan variabel pengembangan karyawan secara bersama-sama mempunyai pengaruh yang signifikan terhadap variabel kepuasan kerja karyawan PT. BPR Kebumen.

Tabel 10 Koefisien Determinasi

Model Summary(b)

\begin{tabular}{|l|c|r|r|r|r|}
\hline $\begin{array}{l}\text { Mod } \\
\text { el }\end{array}$ & $\mathrm{R}$ & $\begin{array}{c}\mathrm{R} \\
\text { Square }\end{array}$ & $\begin{array}{c}\text { Adjusted } \\
\text { R Square }\end{array}$ & $\begin{array}{c}\text { Std. Error } \\
\text { of the } \\
\text { Estimate }\end{array}$ & $\begin{array}{c}\text { Durbin- } \\
\text { Watson }\end{array}$ \\
\hline 1 & $.514(\mathrm{a})$ & .264 & .179 & .39086 & 2.140 \\
\hline
\end{tabular}

a Predictors: (Constant), X3, X1, X2 
Sumber : Hasil Olah Data

b Dependent Variable: Y

Nilai koefisien determinasi $\left(\mathrm{R}^{\mathbf{2}}\right)$ seperti terlihat pada tabel di atas diperoleh nilai 0,264 yang artinya sistem kompensasi, peluang berkarier, dan pengembangan karyawan mempengaruhi kepuasan kerja karyawan PT. BPR Kebumen sebesar 26,4 \%. Dan selebihnya sebanyak 73,6\% dipengaruhi variabel lain yang tidak ada dalam penelitian ini.

\section{Moderated Regression Analysis ( MRA )}

MRA ini digunakan untuk menganalisis pengaruh interaksi dari ketiga variabel bebas ( sistem kompensasi, peluang berkarier, dan pengembangan karyawan ) terhadap variabel terikat ( kepuasan kerja ) dengan motivasi sebagai variabel moderat menggunakan bantuan program SPSS for Windows seri 12. Rumus yang digunakan :

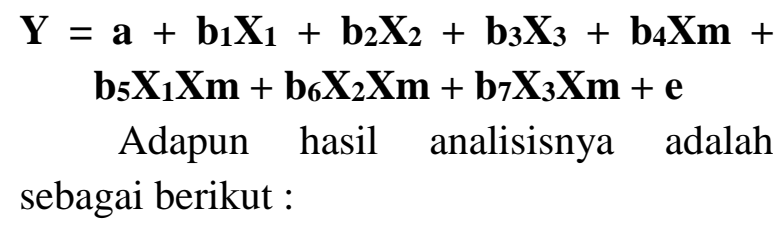

Adapun hasil analisisnya adalah sebagai berikut :

Tabel 11. Koefisien Regresi

\begin{tabular}{|c|c|}
\hline Notasi & Koefisien \\
\hline $\mathrm{a}$ & $-2,151$ \\
$\mathrm{~b}_{1}$ & 1,243 \\
$\mathrm{~b}_{2}$ & 0,282 \\
$\mathrm{~b}_{3}$ & 0,880 \\
$\mathrm{~b}_{4}$ & 0,836 \\
$\mathrm{~b}_{5}$ & $-0,311$ \\
$\mathrm{~b}_{6}$ & $-0,032$ \\
$\mathrm{~b}_{7}$ & $-0,163$ \\
\hline
\end{tabular}

Sumber : Hasil Olah Data

Berdasarkan tabel di atas maka dapat dibuat persamaan regresinya sebagai berikut :

$$
\begin{aligned}
Y= & -2,151+1,243 X_{1}+0,282 X_{2}+ \\
& 0,880 X_{3}+0,836 X_{m}-0,311 X_{1} X_{m}- \\
& 0,032 X_{2} X_{m}-0,163 X_{3} X_{m}+e
\end{aligned}
$$

Kemudian nilai-nilai tersebut di atas dapat dijelaskan satu persatu sebagai berikut :

1. Konstanta ( a ) $=-2,151$, Menunjukkan nilai konstanta atau nilai tetap yang tidak terpengaruh oleh sistem kompensasi, peluang berkarier, dan pengembangan karyawan serta motivasi sebagai variabel moderat. Artinya apabila perusahaan tidak memberikan sistem kompensasi, peluang berkarier, dan pengembangan karyawan yang kemudian diinteraksikan dengan motivasi maka kepuasan kerja karyawan $=-2,151$.

2. Variabel Independen,

a. $b_{1}=0,484$, Koefisien regresi untuk $X_{1}$ sebesar 0,484 artinya setiap penambahan 1 satuan pada variabel sistem kompensasi maka akan meningkatkan kepuasan kerja karyawan sebesar 0,484.

b. $b_{2}=0,065$, Koefisien regresi untuk $X_{2}$ sebesar 0,065 artinya setiap penambahan 1 satuan pada variabel peluang berkarier maka akan meningkatkan kepuasan kerja karyawan sebesar 0,065.

c. $b_{3}=0,265$, Koefisien regresi untuk $X_{3}$ sebesar 0,265 artinya setiap penambahan 1 satuan pada variabel pengembangan karyawan maka akan meningkatkan kepuasan kerja karyawan sebesar 0,265.

d. $\mathrm{b}_{4}=0,836$, koefisien regresi untuk Xm sebesar 0,836 artinya setiap penambahan 1 satuan pada variabel motivasi maka akan meningkatkan kepuasan kerja karyawan sebesar 0,836 . 
e. $b_{5}=-0,311$, Koefisien regresi untuk $\mathrm{X}_{1} \mathrm{Xm}$ sebesar - 0,311 artinya setiap penambahan 1 satuan pada variabel sistem kompensasi yang diinteraksikan dengan motivasi maka kepuasan kerja karyawan sebesar 0,311 .

f. $b_{6}=-0,032$, Koefisien regresi untuk $\mathrm{X}_{2} \mathrm{Xm}$ sebesar - 0,032 artinya setiap penambahan 1 satuan pada variabel peluang berkarier yang diinteraksikan dengan motivasi maka kepuasan kerja karyawan sebesar - 0,032.

g. $b_{7}=-0,163$, Koefisien regresi untuk $\mathrm{X}_{3} \mathrm{Xm}$ sebesar - 0,163 artinya setiap penambahan 1 satuan pada variabel pengembangan karyawan yang diinteraksikan dengan motivasi maka kepuasan kerja karyawan sebesar - 0,163.

\section{Uji Simultan ( Uji F ) MRA}

Table 12 Hasil Uji F MRA

$\operatorname{ANOVA}(\mathbf{b})$

\begin{tabular}{l|l|r|r|r|r|r|}
\hline Model & & $\begin{array}{c}\text { Sum of } \\
\text { Squares }\end{array}$ & \multicolumn{1}{c|}{ df } & Mean Square & F & Sig. \\
\hline 1 & Regression & 1.871 & 7 & .267 & 1.006 & $.454(\mathrm{a})$ \\
& Residual & 5.847 & 22 & .266 & & \\
\multicolumn{2}{|c|}{ Total } & 7.719 & 29 & & & \\
\hline \\
a Predictors: (Constant), X3Xm, X1Xm, X2, Xm, X3, X1, X2Xm \\
b Dependent Variable: Y
\end{tabular}

\section{Sumber : Hasil Olah Data}

Dari hasil pengolahan data seperti terlihat dalam tabel di atas diperoleh tingkat signifikan $0,454>0,05$ yang artinya variabel sistem kompensasi, variabel peluang berkarier, dan variabel

Koefisien Determinasi ( $\mathbf{R}^{2}$ ) MRA pengembangan karyawan dengan variabel moderat motivasi secara bersama-sama tidak berpengaruh signifikan terhadap variabel kepuasan kerja karyawan pada PT. BPR Kebumen.

Table 13 Koefisien Determinasi

Model Summary(b)

\begin{tabular}{|l|r|r|r|r|}
\hline Model & $\mathrm{R}$ & R Square & $\begin{array}{c}\text { Adjusted R } \\
\text { Square }\end{array}$ & $\begin{array}{c}\text { Std. Error of } \\
\text { the Estimate }\end{array}$ \\
\hline 1 & $.492(\mathrm{a})$ & .242 & .001 & .51554 \\
\hline
\end{tabular}

\begin{tabular}{|c|c|c|c|c|c|c|}
\hline \multirow{3}{*}{ Model } & \multicolumn{5}{|c|}{ Change Statistics } & Durbin- \\
\cline { 2 - 5 } & $\begin{array}{c}\text { R Square } \\
\text { Change }\end{array}$ & F Change & df1 & df2 & Sig. F Change & \\
\hline
\end{tabular}




\begin{tabular}{|l|r|r|r|r|r|r|}
\hline 1 & .242 & 1.006 & 7 & 22 & .454 & 2.446 \\
\hline
\end{tabular}
a Predictors: (Constant), X3Xm, X1Xm, X2, Xm, X3, X1, X2Xm
b Dependent Variable: Y

\section{Sumber : Hasil Olah Data}

Nilai koefisien determinasi ( $\mathrm{R}^{2}$ ) untuk Moderated Regression Analysis ( MRA ) seperti terlihat pada tabel di atas diperoleh nilai 0,242 yang artinya sistem kompensasi, peluang berkarier, dan pengembangan karyawan dengan motivasi sebagai variabel moderat mempengaruhi kepuasan kerja karyawan PT. BPR Kebumen sebesar 24,2\%. Dan selebihnya sebanyak 75,8 \% dipengaruhi variabel lain yang tidak ada dalam penelitian ini.

\section{KESIMPULAN}

Berdasarkan hasil analisis data yang telah dilakukan dapat ditarik beberapa kesimpulan sebagai berikut :

1. Berdasarkan karakteristik responden menunjukkan bahwa sebagian besar responden berjenis kelamin pria sebanyak $60 \%$, berumur antara $30-40$ tahun sebanyak 86,67 \%, berlatar belakang pendidikan Diploma ( D3 ) sebanyak $43,33 \%$, dan mempunyai masa kerja lebih dari 10 tahun sebanyak $60 \%$.

2. Berdasarkan hasil uji validitas dan reliabilitas menunjukkan bahwa semua butir kuesioner pada variabel sistem kompensasi, peluang berkarier, pengembangan karyawan, motivasi, dan kepuasan kerja dapat dinyatakan valid dan reliabel. Kemudian dari hasil uji asumsi regresi berganda semua variabel penelitian tidak memiliki masalah dengan multikolinieritas, heteroskedastisitas, dan normalitas sehingga model regresi dapat digunakan.

3. Secara parsial hanya variabel sistem kompensasi yang mempunyai pengaruh signifikan dan positif terhadap kepuasan kerja karyawan pada PT. BPR Kebumen. Ini berarti bahwa semakin baik sistem kompensasi yang diterapkan, semakin tinggi tingkat kepuasan kerja karyawan.

4. Sistem kompensasi, peluang berkarier, dan pengembangan karyawan tanpa variabel moderat motivasi secara bersama-sama mempunyai pengaruh signifikan dan positif terhadap kepuasan kerja karyawan pada PT. BPR Kebumen. Artinya bahwa ketiga variabel tersebut jika dilaksanakan dengan lebih baik, maka semakin tinggi pula tingkat kepuasan kerja karyawan.

5. Secara simultan variabel sistem kompensasi, peluang berkarier, pengembangan karyawan, dan motivasi sebagai variabel moderat tidak berpengaruh signifikan terhadap kepuasan kerja karyawan pada PT. BPR Kebumen. Artinya jika ketiga variabel tersebut dilakukan secara bersama-sama dengan motivasi tidak memberikan pengaruh yang berarti terhadap tingkat kepuasan kerja karyawan.

6. Persentase pengaruh sistem kompensasi, peluang berkarier, dan pengembangan karyawan terhadap kepuasan kerja karyawan pada PT. BPR Kebumen adalah sebesar 26,4 \%. Namun jika diinteraksikan dengan motivasi sebagai variabel moderat, terjadi penurunan pengaruh sebanyak $2,2 \%$ menjadi sebesar $24,2 \%$. 


\section{DAFTAR PUSTAKA}

Bacal, Robert. ( 2002 ). Performance Management. Jakarta : Gramedia.

Davis, Keith. dan John W. Newstrom. ( 1985 ). Perilaku Dalam Organisasi. Jilid 2. Edisi 7. Jakarta : Erlangga.

Ghozali, Imam. ( 2005). Aplikasi Analisis Multivariate dengan Program SPSS. Semarang : BP-UNDIP.

Ghozali, Imam. ( 2005 ). Model Persamaan Struktural, Konsep Dan Aplikasi Dengan Program AMOS Versi 5.0. Edisi 2. Semarang : BP-UNDIP.

Hadi, Sutrisno. ( 1991 ). Analisis Butir Untuk Instrumen, Angket, Tes, Dan Skala Nilai Dengan Basica. Yogyakarta : Andi.

http://one.indoskripsi.com/judul-skripsi/ekonomi-manajemen/analisa-kebijaksanaanpengembangan-karyawan-dalam-meningkatkan-prestasi. Diambil tanggal 07 Nopember 2009.

Istijanto. ( 2008 ). Riset Sumber Daya Manusia Cara Praktis Mendeteksi Dimensi-Dimensi Kerja Karyawan. Jakarta : Gramedia.

Mathis, Robert L. dan John H. Jackson. ( 2001 ). Manajemen Sumber Daya Manusia. Edisi 1. Jakarta : Salemba Empat.

Mathis, Robert L. dan John H. Jackson. ( 2006 ). Human Resource Management. Edisi 10. Jakarta : Salemba Empat.

Nazir, Moh. ( 2003 ). Metode Penelitian. Jakarta : Ghalia Indonesia.

Nurachmad, Much. ( 2009 ). Cara Menghitung Upah Pokok, Uang Lembur, Pesangon, Dan Dana Pensiun. Jakarta : Visimedia.

Panudju, Agung. ( 2003 ). "Pengaruh Kompensasi dan Karakteristik Pekerjaan Terhadap Kepuasan Kerja Karyawan Unit Produksi PT X Palembang.” Jurnal Manajemen Dan Bisnis Sriwijaya. Vol. 1. No. 2.

Schuler, Randall S. dan Susan E. Jackson. ( 1999 ). Manajemen Sumber Daya Manusia Menghadapi Abad Ke-21. Jilid 2. Edisi 6. Jakarta : Erlangga.

Singarimbun, Masri. dan Sofyan Efendi, ( 1995 ). Metode Penelitian Survei. Jakarta : LP3ES.

Sugiyono. ( 2003 ). Statistika untuk Penelitian. Bandung : Alfabeta.

Sugiyono. ( 2005 ). Metode Penelitian Administrasi. Edisi 12. Bandung : Alfabeta.

Widodo, Parwoto. ( 2009 ). "Pengaruh Lingkungan Kerja Pada Hubungan Antara Kompensasi Dan Kepemimpinan Terhadap Kepuasan Kerja Studi Pada Kantor Pelayanan Pajak Salatiga." Diambil tanggal 20 Nopember 2009 dari http://eprints.ums.ac.id/800/1/Jurnal Daya Saing15.pdf.

Wikipedia. ( 2009 ). "Kepuasan Kerja." Diambil tanggal 28 Oktober 2009 dari http://id.wikipedia.org/wiki/kepuasan kerja. 